\title{
Synthesis and Structural Properties of Bismuth Doped Cobalt Nanoferrites Prepared by Sol-Gel Combustion Method
}

\author{
Naraavula Suresh Kumar' ${ }^{1}$ Katrapally Vijaya Kumar ${ }^{2 *}$ \\ ${ }^{1}$ Mallareddy Institute of Engineering \& Technology, Secunderabad, India \\ ${ }^{2}$ Department of Physics, JNTUH College of Engineering Jagtial, Nachupally (Kondagattu), Karimnagar-Dist, TS, \\ India \\ Email: "kvkphd@gmail.com
}

Received 8 October 2015; accepted 8 December 2015; published 11 December 2015

Copyright (C) 2015 by authors and Scientific Research Publishing Inc.

This work is licensed under the Creative Commons Attribution International License (CC BY). http://creativecommons.org/licenses/by/4.0/

(c) (i) Open Access

\begin{abstract}
A series of Bismuth doped Cobalt nanoferrites of chemical composition $\mathrm{CoBi}_{\mathrm{x}} \mathrm{Fe}_{2-\mathrm{x}} \mathrm{O}_{4}$ (where $\mathrm{x}=$ $0.00,0.05,0.10,0.15,0.20 \& 0.25$ ) were prepared by sol-gel combustion method and calcinated at $600^{\circ} \mathrm{C}$. The structural and morphological studies were carried out by using X-ray diffraction (XRD), Scanning Electron Microscope (SEM), Transmission Electron Microscopy (TEM), Energy Dispersive Spectroscopy (EDS) and Fourier Transform Infrared (FT-IR) spectra showing the single phase spinal structure. The X-ray diffraction (XRD) analysis confirmed a single phase fcc crystal. The crystallite size of all the compositions was calculated using Debye-Scherrer equation and found in the range of 17 to $26 \mathrm{~nm}$. The lattice parameters were found to be decreased as $\mathrm{Bi}^{3+}$ ion doping increases. The surface morphology was studied by Scanning Electron Microscope (SEM) and particle size was confirmed by Transmission Electron Microscopy (TEM). The EDS plots revealed existence of no extra peaks other than constituents of the taken up composition. The Fourier Transform Infrared (FT-IR) studies were made in the frequency range $350-900 \mathrm{~cm}^{-1}$ and observed two strong absorption peaks. The frequency band is found at $596 \mathrm{~cm}^{-1}$ where as the lower frequency band at $393 \mathrm{~cm}^{-1}$. It is clearly noticed that the two prominent absorption bands were slightly shifted towards higher frequency side with the increase of $\mathrm{Bi}^{3+}$ ion concentration.
\end{abstract}

\section{Keywords}

Bi-Co Nanoferrites, Sol-Gel Combustion Method, XRD, SEM, EDS, TEM and FTIR

\footnotetext{
"Corresponding author.
}

How to cite this paper: Suresh Kumar, N. and Vijaya Kumar, K. (2015) Synthesis and Structural Properties of Bismuth Doped Cobalt Nano Ferrites Prepared by Sol-Gel Combustion Method. World Journal of Nano Science and Engineering, 5, $140-151$. http://dx.doi.org/10.4236/wjnse.2015.54016 


\section{Introduction}

In recent years the research on metal nanoferrites has been the subject of much interest due to their unusual structural, magnetic, dielectric and electrical properties. Specifically the materials with nano scale of dimensions in the range 1 - $100 \mathrm{~nm}$ show great physical and chemical properties. The nano-size materials attribute increase in relative surface area with decreased particle size leads quantum size effects [1] [2]. The nano particles dramatically change some of the magnetic properties and exhibit super paramagnetic phenomena and quantum tunnelling of magnetisation because each particle can be considered as a single magnetic domain [3]-[5]. In general the nano ferrite materials have high resistivity i.e., low electrical conductivity, moderate saturation magnetization, high coercivity, mechanical hardness and chemical stability [6]-[9]. Any Metal ferrite has the spinal structure belonging to a general formula $\mathrm{M}^{2+} \mathrm{Fe}_{2}^{3+} \mathrm{O}_{4}$ (also well known formula $\mathrm{AB}_{2} \mathrm{O}_{4}$ ) crystallizing with spinal structure, in which " $\mathrm{M}$ ” represents tetrahedral site and "Fe" represents the octahedral site respectively and $\mathrm{O}$ indicates anion site. Finally, the novel properties of the spinal ferrites result with their ability of distributions among the tetrahedral and octahedral sites [10] [11]. For obtaining the specific properties ferrites can be fabricated by substituting various magnetic and non magnetic ions which greatly affect the magnetic moments, lattice parameters and exchanging interactions. Cobalt Ferrite $\left(\mathrm{CoFe}_{2} \mathrm{O}_{4}\right)$ is a spinal structured ceramic oxide and well known hard magnetic material with high coercivity and moderate magnetisation. The properties of ferrite materials are known to be strongly influenced by their composition and microstructure. Doping of Cobalt ferrite with one or several metals is the best method to alter its physical and chemical properties. Bismuth Ferrite (BFO) is one of the most important single phase multi ferroic materials due to their high electrical resistivity, low magnetic and dielectric losses [12] [13]. And it is reported that on substituting of bismuth in very small amount does not alter the spinal structure of Cobalt ferrite. From the literature, we found that very less people worked on substitution of Bismuth ferrites [13]-[15]. With the great physicochemical properties and thermal stability, Bismuth doped Cobalt nanoferrites are suitable for magnetic recording applications such as audio, videotapes and high density digital recording discs. Therefore, $\mathrm{Bi}_{2} \mathrm{O}_{3}$ is a potential substitution for improving the magnetic and electrical properties of ferrites. There are several methods to synthesize nanoferrites such as solid state reaction, co-precipitation, sol-gel method, reverse micelles and hydrothermal method [16]. Among all the sol-gel combustion method is a simple method which speeds up the synthesis of complex materials and brings crystal uniformity [1]. Hence, in this paper we have reported the synthesis and structural characterisations of Bismuth doped Cobalt nonoferrites with the chemical composition $\mathrm{CoBi}_{\mathrm{x}} \mathrm{Fe}_{2-\mathrm{x}} \mathrm{O}_{4}$ (where $\mathrm{x}=0.00$ to 0.25).

\section{Experimental}

High purity crystalline nanoferrites were prepared by employing sol-gel combustion method. It is probably most effective method for the synthesis of homogenous nano particles which can be prepared at relatively low temperature [17].

\subsection{Raw Materials}

A series of Bismuth substituted cobalt nanoferrites having the chemical formula $\mathrm{CoBi}_{\mathrm{x}} \mathrm{Fe}_{2-\mathrm{x}} \mathrm{O}_{4}$ (where $\mathrm{x}=0.00$, $0.05,0.10,0.15,0.20,0.25)$ were prepared by sol-gel method. The starting materials were cobaltus nitrate $\left[\mathrm{Co}\left(\mathrm{No}_{3}\right)_{2} \cdot 6 \mathrm{H}_{2} \mathrm{O}\right]$ with $99 \%$ purity from sd-fine chemicals, bismuth Nitrate $\left[\mathrm{Bi}\left(\mathrm{No}_{3}\right)_{3} \cdot 5 \mathrm{H}_{2} \mathrm{O}\right]$ with $98.9 \%$ purity from sd-fine chemicals, ferric nitrate $\left[\mathrm{Fe}\left(\mathrm{No}_{3}\right)_{3} \cdot 9 \mathrm{H}_{2} \mathrm{O}\right]$ with $99.1 \%$ purity from sd-fine chemicals, citric acid $\left[\mathrm{C}_{6} \mathrm{H}_{8} \mathrm{O}_{7} \cdot \mathrm{H}_{2} \mathrm{O}\right]$ with $99.9 \%$ purity from sd-fine chemicals, $25 \%$ of aqueous solution of ammonia $\left(\mathrm{NH}_{3}\right)$ with $\mathrm{A}-$ grade from sd-fine chemicals.

\subsection{Synthesis}

The stoichiometric amount of all metal nitrates were dissolved in different glass beakers with minimum quantity of double distilled water and mixed together with the help of magnetic stirrer. Later on a solution of citric acid was added to the mixed metal solution with molar ratio of nitrates to citric acid is 1:3. Under constant stirring an aqueous solution of ammonia $\left(\mathrm{NH}_{3}\right)$ was added to this nitrate mixture drop wise to adjust the $\mathrm{pH}$ value about to 7. And finally a homogeneous solution was obtained. Then the mixed solution was heated about $100^{\circ} \mathrm{C}$ with uniform stirring and evaporated to obtain a highly viscous gel. The resultant gel was further heated $180^{\circ} \mathrm{C}$ to $200^{\circ} \mathrm{C}$. When all water molecules were removed from the mixture, the gel gave a fast flameless auto combustion 
reaction with the evolution of gaseous products. And after some time it starts in the hottest zones of the beaker and propagated from the bottom to the top like the eruption of a volcano. After completion of this reaction a dark brown ash powder was yielded at $250^{\circ} \mathrm{C}$ with a structure similar to branched tree. All these synthesis process was outlined in the following Figure 1. At last it is cooled to room temperature and ground in an agate mortar for at least 30 minutes to get a highly dense power. Finally the powder was sintered at $600^{\circ} \mathrm{C}$ for 5 hours in air and cooled to room temperature. Further the prepared compositions were characterised by XRD, SEM, EDS, TEM and FTIR.

\subsection{Characterization}

The structural characterization of synthesized samples were carried out XRD by Phillips X-ray Diffractometer (model 3710) using with $\mathrm{Cu} \mathrm{K} \alpha(\lambda=1.54 \AA$ ) radiation. This was operated at room temperature by continuous scanning with $2 \theta$ values in the range of $10^{\circ}$ to $80^{\circ}$ to investigate phase, crystallite size and lattice parameters. The surface morphology of the samples was examined by using Scanning Electron Microscope (SEM) and the micro structural analysis of the prepared samples was carried out by Transmission Electron Microscope (TEM). The elemental analysis was carried out by using Energy Dispersive Spectrometer (EDS), which confirm the purity of all prepared samples. The infrared spectra of synthesized powders were recorded by SHIMADZU Fourier Transform Infrared Spectrophotometer (FT-IR), Model P/N-206-73500-38, in the range of 4000 to $250 \mathrm{~cm}^{-1}$ with a resolution of $4 \mathrm{~cm}^{-1}$, which reveals the formation of single phase cubic spinal structure.

\section{Results and Discussion}

\subsection{XRD Analysis}

X-ray diffraction patterns of composition $\mathrm{CoBi}_{\mathrm{x}} \mathrm{Fe}_{2-\mathrm{x}} \mathrm{O}_{4}(\mathrm{x}=0.0$ to 0.25$)$ nano ferrite particles are shown in Figure 2. Generally for a pure cobalt ferrite the XRD pattern exhibits eight peaks which were located in between

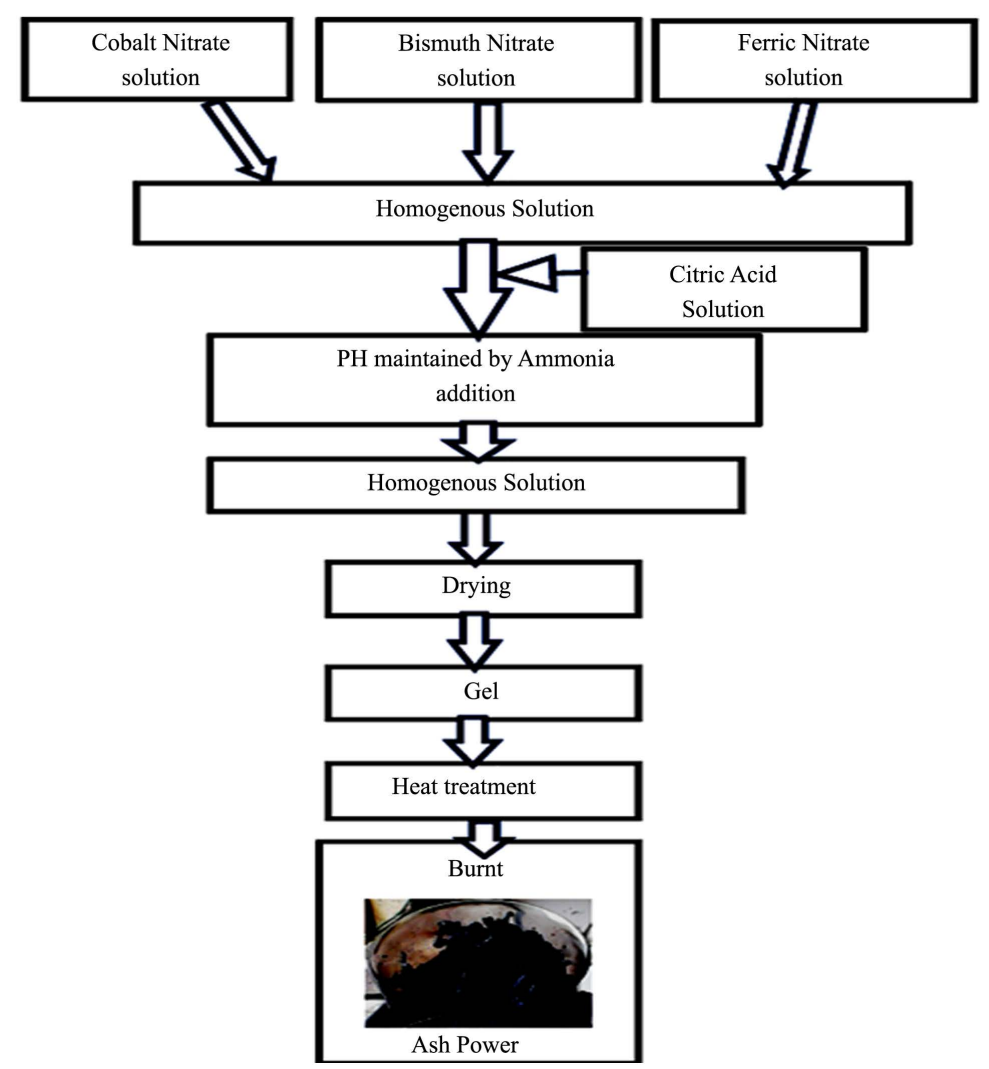

Figure 1. A general flowchart for the synthesis of $\mathrm{CoBi}_{\mathrm{x}} \mathrm{Fe}_{2-\mathrm{x}} \mathrm{O}_{4}$ nano ferrite particles. 


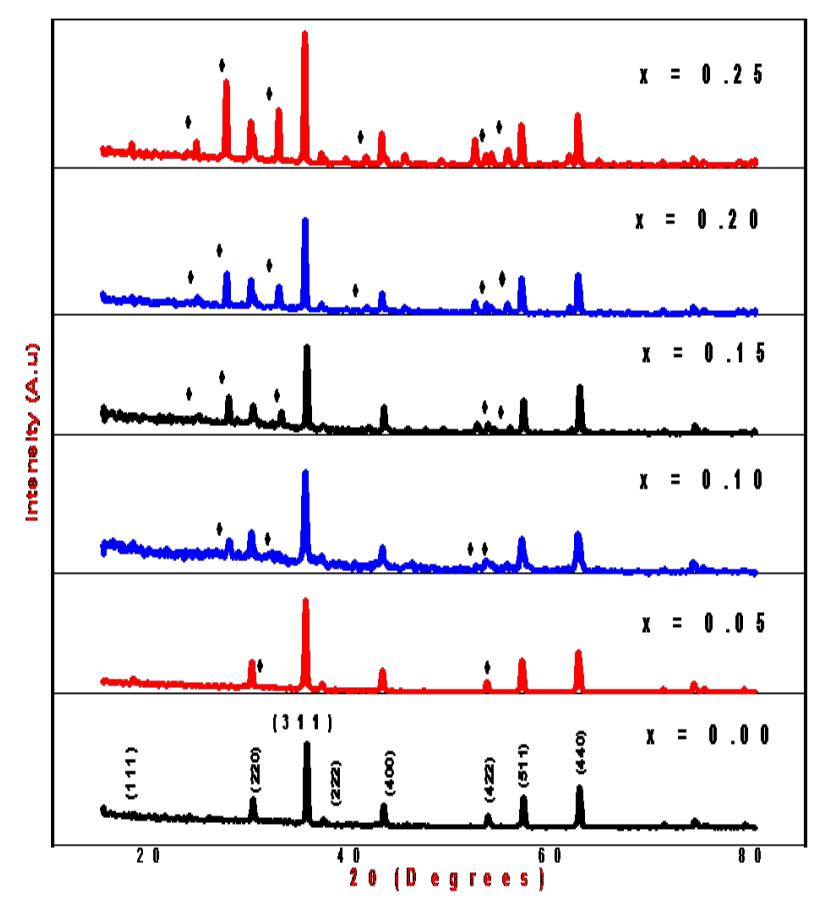

Figure 2. The XRD pattern of $\mathrm{CoBi}_{\mathrm{x}} \mathrm{Fe}_{2-\mathrm{x}} \mathrm{O}_{4}$ nano ferrite particles.

$2 \theta=15^{\circ}$ to $80^{\circ}$ as follows. In which the corresponding intensities of the peaks displayed as percentage (\%) of the most intensive peak located with relative miller indices are shown in Table 1 [18]. The XRD pattern matches with the (JCPDS-KDD) file number of (22-1086) and the corresponding reflections of peaks (220), (311), (400), (333), (440) were observed in X-ray diffraction pattern. On substitution of Bismuth in very small amount which does not alter the spinal structure of ferrite system [19]. It is also observed that the Bragg's peaks confirm the formation of a single phase fcc spinal structure. From the XRD pattern it is identified for $\mathrm{x}=0.00$ shows only peaks consistent with cubic spinal phase and rest of all the samples with the composition, $x=0.05$ to 0.25 , have additional peaks marked with the "»" sign in Figure 2, which corresponds to the element of Bismuth. The crystallite sizes of all compositions were determined from broadening of the peak (311) of XRD pattern using the following Debye-Scherrer formula.

$$
D=\frac{0.9 \lambda}{\beta \cos \theta}
$$

where, $D=$ the average crystallite size of the phase under investigation, $\lambda=$ wavelength of X-ray beam used, $\beta=$ full width at half maxima (FWHM) in radians and $\theta=$ Bragg's angle.

From Table 2, it is observed that the lattice parameter decreases as the Bismuth concentration increases. The decrease in lattice constant (a) is due to the difference in ionic radii of $\mathrm{Bi}^{3+}(0.74 \AA)$ as compared to $\mathrm{Fe}^{3+}(0.78$ $\AA$ ). Therefore the smaller $\mathrm{Bi}^{3+}$ ions were replaces the larger $\mathrm{Fe}^{3+}$ ions completely in octahedral positions [20] and the crystalline size was found to be in the range of 17 to $26 \mathrm{~nm}$ which was good agreement with XRD result.

The lattice parameter "a" was calculated using the following equation.

$$
a=d \sqrt{h^{2}+k^{2}+l^{2}}
$$

Figure 3 shows the variation of lattice constant (a) with the composition (X), which indicates that the variation of lattice constant (a) is found to be decrease linearly with increase of $\mathrm{Bi}^{3+}$ ion content. The unit cell volume was calculated as $V=a^{3}$ in atomic units (where $a=$ lattice constant). If we speak in terms of volume, it is clear that the volume of unit cell depends on the lattice constant (a). The increase of bismuth doping in the composition, the lattice constant and the volume of unit cell were decreased linearly [21]. Several investigators were observed the similar behaviour of lattice constants with doping concentration. The decrease in lattice parameter on 


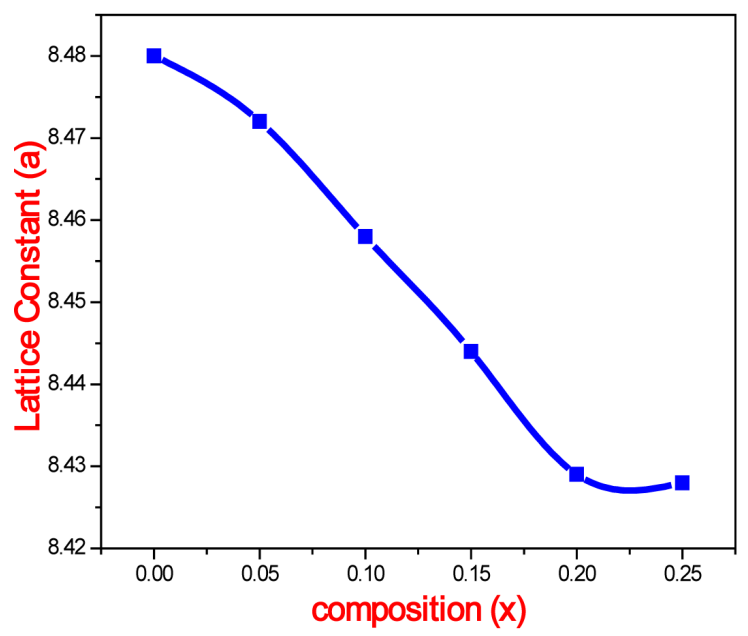

(a)

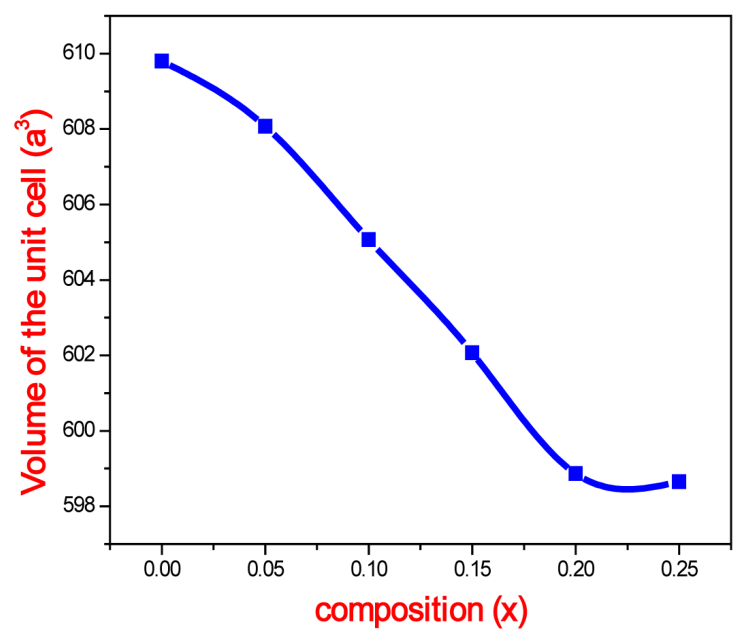

(b)

Figure 3. (a)-(b) shows the variation of lattice constant (a) and volume of the unit cell with the composition (X) of $\mathrm{CoBi}_{\mathrm{x}} \mathrm{Fe}_{2-\mathrm{x}} \mathrm{O}_{4}$ nano ferrite particles.

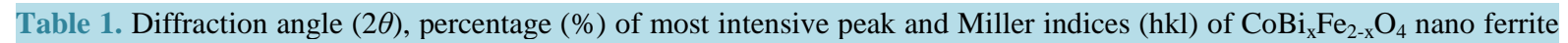
particles.

\begin{tabular}{ccc}
\hline Diffraction angle $(2 \theta)$ & \% of most intense peak & Miller indices (h k l) \\
\hline 18.289 & $10 \%$ & $(111)$ \\
30.085 & $30 \%$ & $(220)$ \\
35.438 & $100 \%$ & $(311)$ \\
37.057 & $8 \%$ & $(222)$ \\
43.059 & $20 \%$ & $(400)$ \\
53.446 & $10 \%$ & $(422)$ \\
56.975 & $30 \%$ & $(511)$ \\
62.587 & $40 \%$ & $(440)$ \\
\hline
\end{tabular}

Table 2. Values of crystallite size (D), lattice constant (a), inter planar distance (d) and unit cell volume (a $\left.{ }^{3}\right)$ of $\mathrm{CoBi}_{x} \mathrm{Fe}_{2-\mathrm{x}} \mathrm{O}_{4}$ nano ferrite particles.

\begin{tabular}{cccccc}
\hline $\mathrm{X}$ & Composition & Crystallite size (D) nm & Lattice constant (a) $\AA$ & $\begin{array}{c}\text { Volume of the } \\
\text { unit cell }\left(\mathrm{a}^{3}\right) \mathrm{cm}^{3}\end{array}$ & $\begin{array}{c}\text { Inter planar } \\
\text { spacing }(\mathrm{d}) \AA\end{array}$ \\
\hline 0.00 & $\mathrm{CoFe}_{2} \mathrm{O}_{4}$ & 26.458 & 8.480 & 609.800 & 2.550 \\
0.05 & $\mathrm{CoBi}_{0.05} \mathrm{Fe}_{1.95} \mathrm{O}_{4}$ & 26.450 & 8.472 & 608.075 & 2.541 \\
0.10 & $\mathrm{CoBi}_{0.10} \mathrm{Fe}_{1.90} \mathrm{O}_{4}$ & 24.020 & 8.458 & 605.066 & 2.546 \\
0.15 & $\mathrm{CoBi}_{0.15} \mathrm{Fe}_{1.85} \mathrm{O}_{4}$ & 17.631 & 8.444 & 602.066 & 2.541 \\
0.20 & $\mathrm{CoBi}_{0.20} \mathrm{Fe}_{1.80} \mathrm{O}_{4}$ & 17.630 & 8.429 & 598.863 & 2.554 \\
0.25 & $\mathrm{CoBi}_{0.25} \mathrm{Fe}_{1.75} \mathrm{O}_{4}$ & 17.627 & 8.428 & 598.650 & 2.557 \\
\hline
\end{tabular}

the basis of relative ionic radii of $\mathrm{Cr}^{3+}$ and $\mathrm{Fe}^{3+}$ ions [22] [23].

The X-ray densities were calculated using the following Formula (3) and were tabulated in Table 2.

$$
X-\text { ray density }\left(d_{x}\right)=\frac{8 M}{N a^{3}}\left(\mathrm{gm} / \mathrm{cm}^{3}\right)
$$

where, $M=$ Molecular weight of the sample, $N=$ Avogadro number, $a$ = lattice constant.

The variation of X-ray density $\left(d_{x}\right)$ and porosity $(\mathrm{P})$ with the composition $(\mathrm{X})$ is shown in Figure 4 . In any 
ferrite system the variation of X-ray density with composition depends on the lattice constant (a) and total molecular weight $(\mathrm{M})$ of the sample [24]. In this series from the Table 3, it was clear that as the $\mathrm{Bi}^{3+}$ ion content increases, the total molecular weight of the sample was also increases. This is due to the increase in mass overtakes the decrease in volume of the unit cell. Therefore greater atomic weight of bismuth ions $(208.98 \mathrm{gm} / \mathrm{mol})$ were replaces completely with lesser atomic weight of ferric ions $(55.85 \mathrm{gm} / \mathrm{mol})$. From Table 2 and Table 3 it is clearly shown that, the lattice parameter decreases with the increase of bismuth ion composition. Hence from Figure 4 shows the X-ray density $\left(d_{x}\right)$ increases with increase of total molecular weight and it also confirms that the porosity decreases linearly with the composition $(X)$. A similar behaviour of X-ray density with Cr-substitution was presented by Md. Javed Iqbal, Mah Rukh, Sidiqyah in Co-Cr ferrite system [25].

The distance between magnetic ions (hopping length) in A-site (tetrahedral) and B-site (octahedral) were calculated using the relations (4) \& (5) [23].

$$
\begin{aligned}
& d_{A}=0.25 a \sqrt{3} \\
& d_{B}=0.25 a \sqrt{2}
\end{aligned}
$$

where, $d_{A}=$ hopping length for tetrahedral site, $d_{B}=$ hopping length for octahedral site and $a=$ lattice constant.

The calculated values of $d_{A}$ and $d_{B}$ of different compositions were tabulated in Table 3 . The variation of hopping length for octahedral and tetrahedral sites with $\mathrm{Bi}^{3+}$ ion composition is shown in Figure 5 and it was observed that the hopping length were decreases with the increase of bismuth composition. It may be due to smaller ionic radius of the $\mathrm{Bi}^{3+}(0.74 \AA)$ than $\mathrm{Fe}^{3+}(0.78 \AA)[21]$.

\subsection{SEM}

The Scanning Electron Microscopic (SEM) images of all the synthesized samples were shown in Figure 6. The

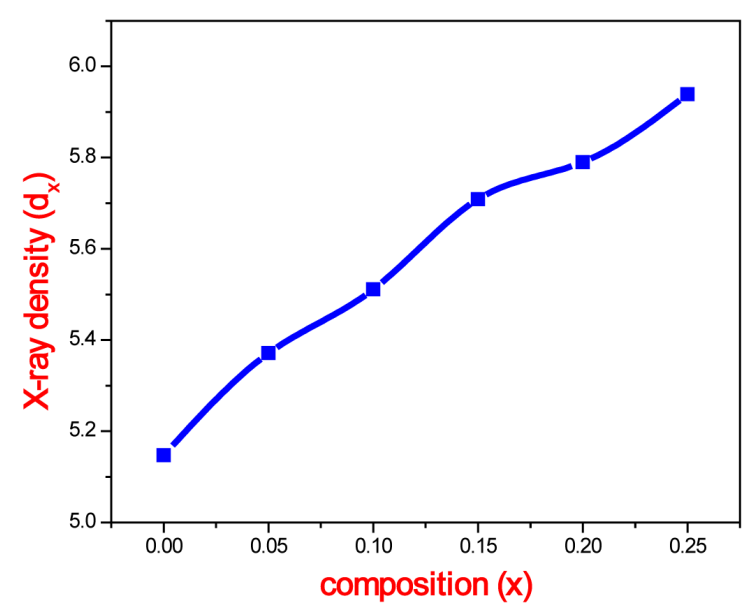

(a)

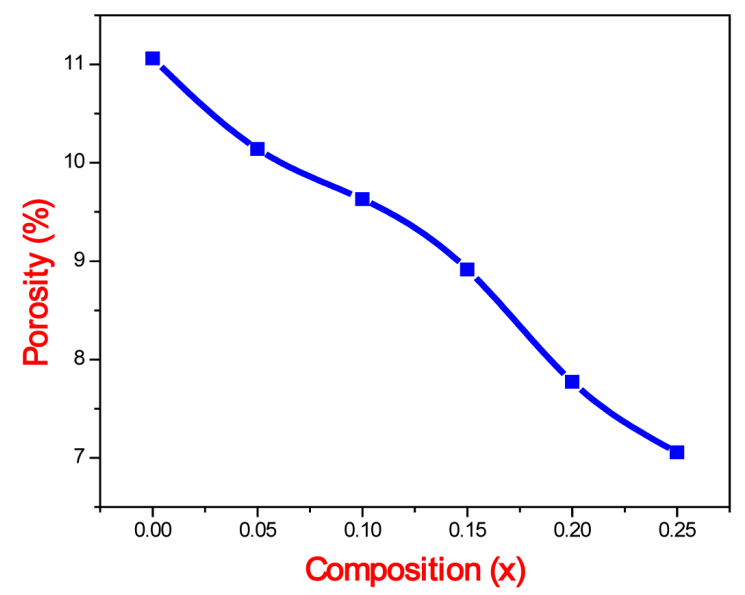

(b)

Figure 4. (a) (b) shows the variation of X-ray density $\left(\mathrm{d}_{\mathrm{x}}\right)$ and porosity (P) with the composition (X) of $\mathrm{CoBi}_{\mathrm{X}} \mathrm{Fe}_{2-\mathrm{x}} \mathrm{O}_{4}$ nano ferrite particles.

\begin{tabular}{|c|c|c|c|c|c|c|c|}
\hline Sample & Composition & $\begin{array}{l}\text { Molecular weight } \\
\text { (M) } \mathrm{gm} / \mathrm{mol}\end{array}$ & $\begin{array}{c}\text { X-ray density }\left(d_{x}\right) \\
\text { gm/cc }\end{array}$ & $\begin{array}{c}\text { Bulk density }\left(d_{B}\right) \\
\text { gm/cc }\end{array}$ & Porosity (P) \% & A-site $\left(d_{A}\right) \AA$ & B-site $\left(d_{B}\right) \AA$ \\
\hline$X=0.00$ & $\mathrm{CoFe}_{2} \mathrm{O}_{4}$ & 234.627 & 5.147 & 4.57 & 11.21 & 3.6718 & 2.9981 \\
\hline$X=0.05$ & $\mathrm{CoBi}_{0.05} \mathrm{Fe}_{1.95} \mathrm{O}_{4}$ & 242.284 & 5.371 & 4.82 & 10.14 & 3.6683 & 2.9952 \\
\hline$X=0.10$ & $\mathrm{CoBi}_{0.10} \mathrm{Fe}_{1.90} \mathrm{O}_{4}$ & 249.942 & 5.511 & 4.98 & 9.63 & 3.6623 & 2.9903 \\
\hline$X=0.15$ & $\mathrm{CoBi}_{0.15} \mathrm{Fe}_{1.85} \mathrm{O}_{4}$ & 257.597 & 5.709 & 5.20 & 8.915 & 3.6562 & 2.9853 \\
\hline$X=0.20$ & $\mathrm{CoBi}_{0.20} \mathrm{Fe}_{1.80} \mathrm{O}_{4}$ & 265.253 & 5.790 & 5.34 & 7.772 & 3.6497 & 2.9800 \\
\hline$X=0.25$ & $\mathrm{CoBi}_{0.25} \mathrm{Fe}_{1.75} \mathrm{O}_{4}$ & 272.910 & 5.939 & 5.52 & 7.055 & 3.6493 & 2.9797 \\
\hline
\end{tabular}

Table 3. Various structural parameters of $\mathrm{CoBi}_{x} \mathrm{Fe}_{2-\mathrm{x}} \mathrm{O}_{4}$ nano ferrite particles. 


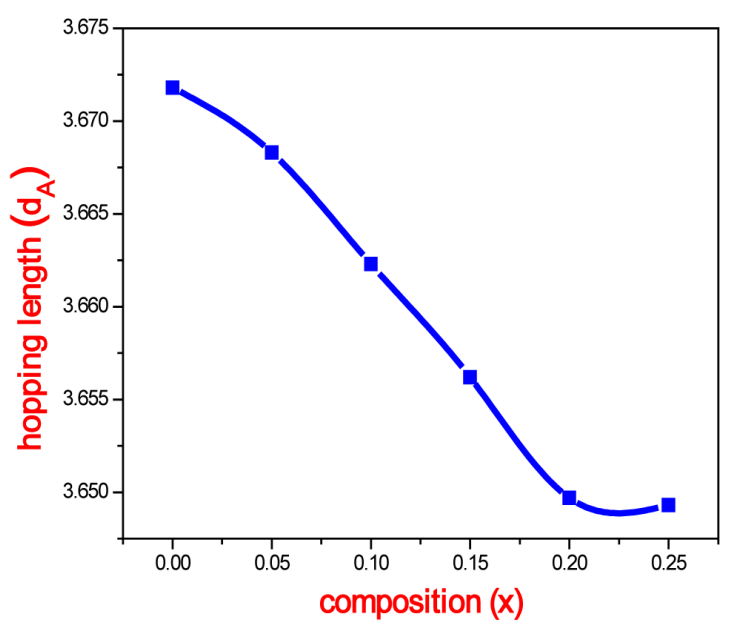

(a)

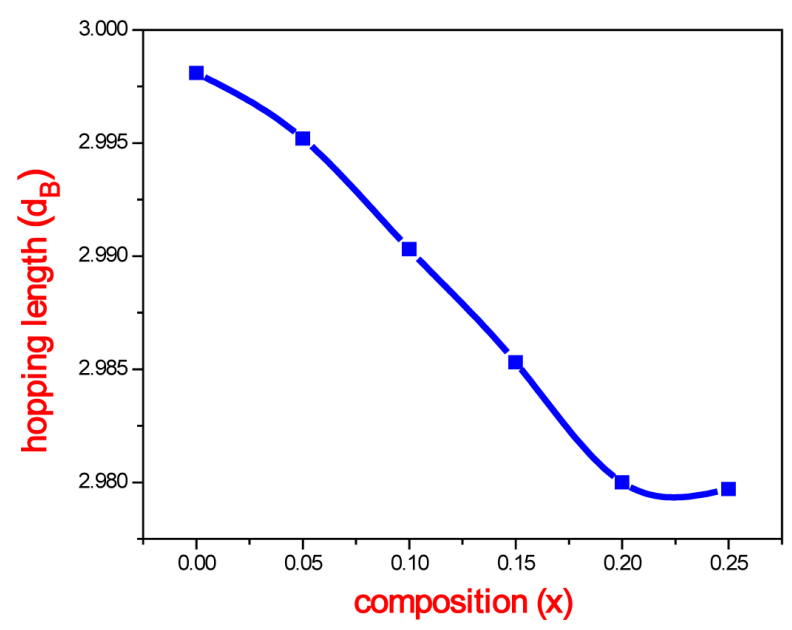

(b)

Figure 5. (a)-(b) shows the distance between magnetic ions in both tetrahedral $\left(\mathrm{d}_{\mathrm{A}}\right)$ and octahedral $\left(\mathrm{d}_{\mathrm{B}}\right)$ sites as a function of composition (x) of $\mathrm{CoBi}_{\mathrm{x}} \mathrm{Fe}_{2-\mathrm{x}} \mathrm{O}_{4}$ nano ferrite particles.

morphology of the prepared samples by sol-gel combustion method was studied by SEM (Scanning Electron Microscope) technique. The prepared samples of composition $(x=0.00$ to 0.25$)$ have been presented and secondary electron images were taken at different magnifications. It is clear that the SEM images show that the particles have an almost homogeneous distribution and some of them are agglomerated form. It is evidenced by SEM images that the aggregation of particles lies in nanometre region. The formation of ferrite was during sintering the pores between the particles were removed and formed strong bonds in the agglomeration form [24]. The interaction of grain boundary and porosity is important in determining the limited grain size of the particles. With this study it can be observed that the average grain size of the particles were decreasing trend with $\mathrm{Bi}^{3+}$ ion doping, moreover it is slightly lesser than determined by XRD and conforming the synthesized samples were crystalline structure.

\subsection{TEM}

Figures 7 (a)-(c) Show images of Transmission Electron Microscope (TEM) and Selected Area Electron Diffraction (SAED) patterns of cobalt ferrite of the sample $\mathrm{x}=0.10$ sintered at $600^{\circ} \mathrm{C}$. The TEM micrographs of these samples show the complete view about crystallite size, morphology and micro structure. From Figure 7(a), it can be observed that the particles were rounded in cubic shape and formed loose aggregates and the particle size was found $50 \mathrm{~nm}$ which was a good agreement to XRD result. Some separated particles are also seen in those samples. However some moderately agglomerated particles as well as separated particles also present in the images. Which is due to increases with sintering temperature and hence some degree of agglomeration at this $600^{\circ} \mathrm{C}$ appears which unavoidable [25] [26].

The corresponding selective area electron diffraction (SAED) analysis of the sample $x=0.10$ were shown in Figure 7(b) and Figure 7(c). This indicates that Bismuth doped cobalt ferrite nano particles were found wellcrystalline in nature. According to this diffraction pattern the measured lattice constant and inter planar spacing $\mathrm{d}_{(\mathrm{hkl})}$ agrees well with the XRD result.

\subsection{EDS}

The elemental analysis of the Co-Bi nano ferrite samples with different compositions was done by Energy dispersive spectrometer (EDS). The product of $\mathrm{CoBi}_{\mathrm{x}} \mathrm{Fe}_{2-\mathrm{x}} \mathrm{O}_{4}$ of all the compositions has been determined by the EDS and the patterns obtained are shown in Figure 8. All the EDS images show the presence of Co, Bi, Fe and Oxygen in the sample which did not contain the elements of $\mathrm{Na}$ and other elements. So the results indicated that the cation $\mathrm{Na}^{+}$did not take part in the reaction. Most of the undesired precursor materials like chloride ions have been completely removed from quantification of the peaks were found to be values of 1:1:1 and the elemental \% and atomic \% of different elements were shown in Table 4. 

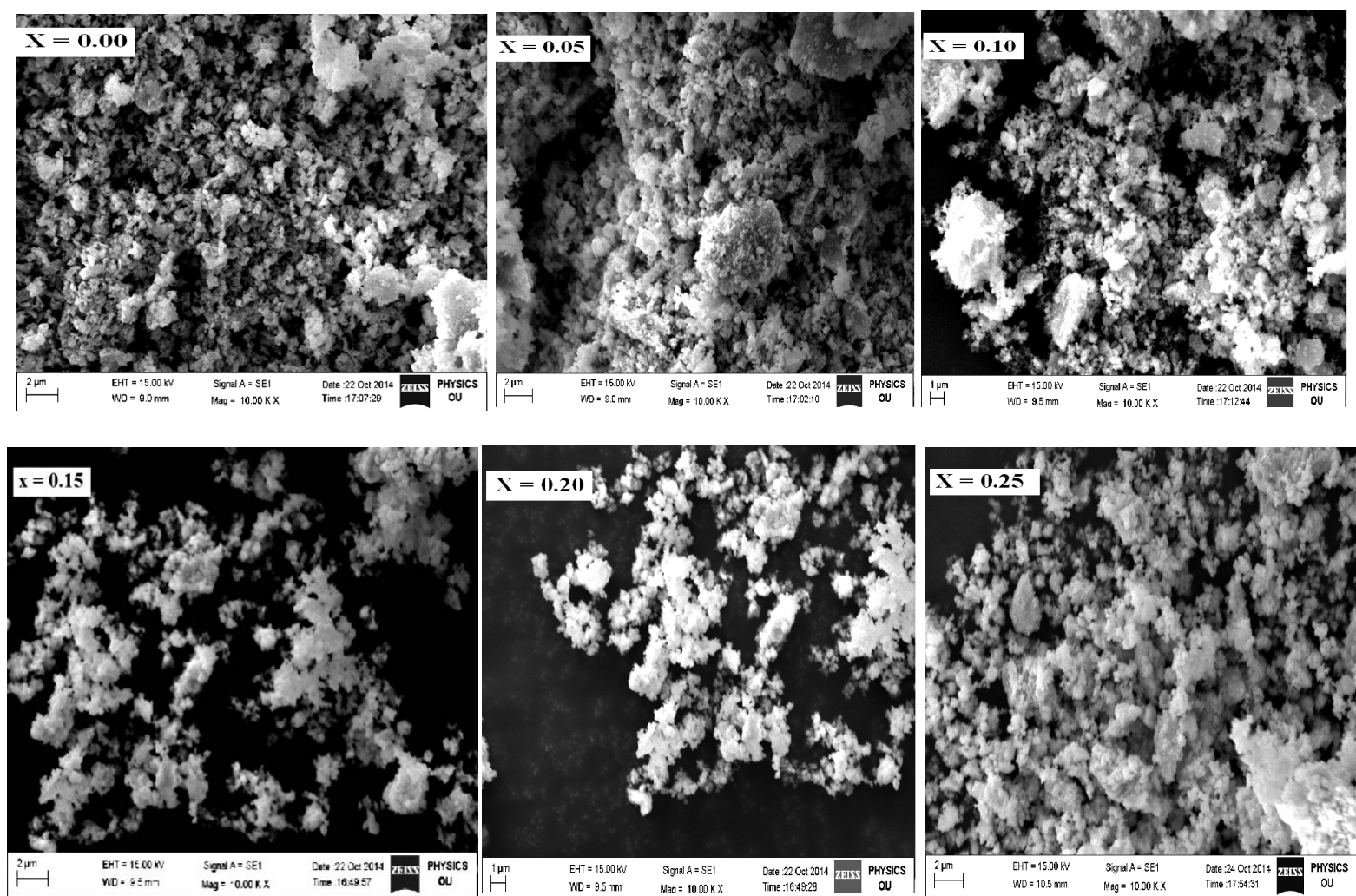

Figure 6. Shows the SEM image of all Co-Bi ferrite (CBF) nano particles which are sintered at $600^{\circ} \mathrm{C}$ of $\mathrm{CoBi}_{\mathrm{x}} \mathrm{Fe}_{2-\mathrm{x}} \mathrm{O}_{4} \mathrm{nano}$ ferrite particles.
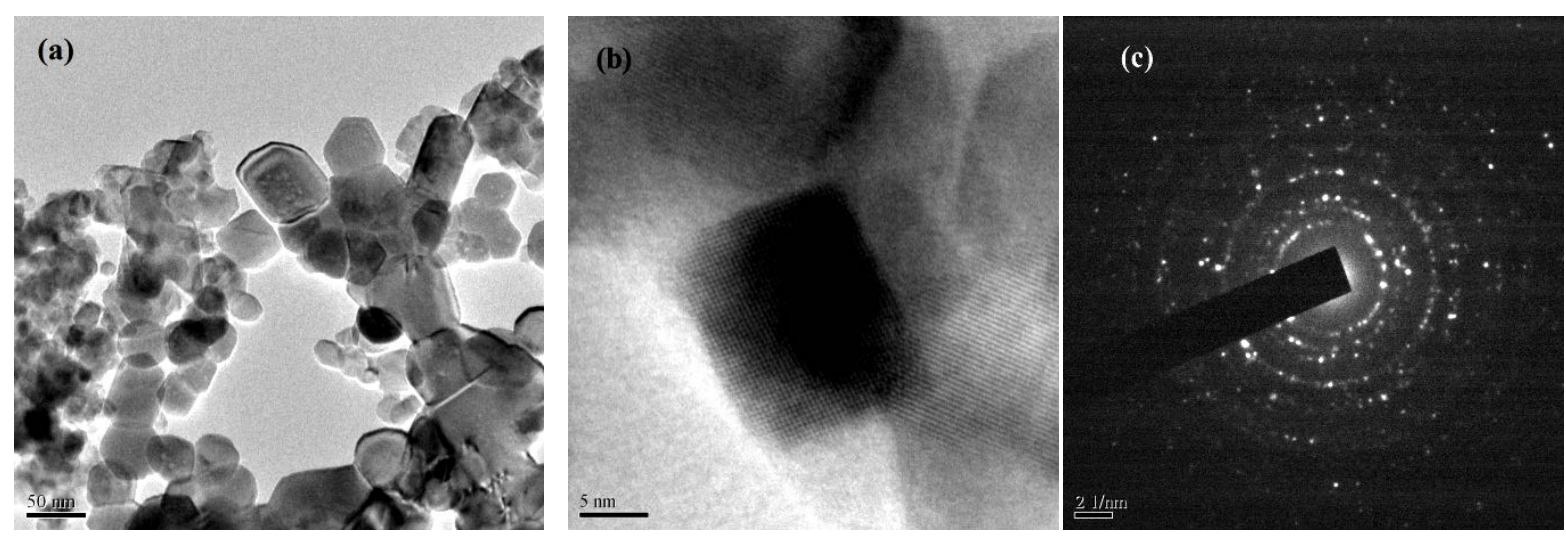

Figure 7. (a)-(c) shows TEM and SAED images of $\mathrm{CoBi}_{\mathrm{x}} \mathrm{Fe}_{2-\mathrm{x}} \mathrm{O}_{4}$ nano ferrite particles of $\mathrm{x}=0.10$.

\subsection{FTIR}

FTIR spectroscopic analysis is an additional tool for the structural characterisation of the spinal structure of Co-Bi ferrite system. The Figure 9 shows FT-IR spectra of $\mathrm{CoBi}_{\mathrm{x}} \mathrm{Fe}_{2-\mathrm{x}} \mathrm{O}_{4}(\mathrm{x}=0.00$ to 0.25$)$ nano ferrite particles at room temperature in the range of 350 to $900 \mathrm{~cm}^{-1}$. The spectra of all the ferrites have been used to locate the band positions which are summarized in the Table 5 . In the present study two prominent absorption bands $v_{1}$ and $v_{2}$ are found at around 596.15 and $393.50 \mathrm{~cm}^{-1}$ respectively for all the compositions. The absorption bands observed within the specific limits reveal the formation of single phase spinal structure having two sub lattices, i.e., tetrahedral (A-site) and octahedral (B-site) [27]. The high frequency band $v_{1}$ called strongest absorption lies in the range 591.33 to $596.15 \mathrm{~cm}^{-1}$ while the low frequency band $v_{2}$ called weakest absorption lies in the range of 384.09 to $393.50 \mathrm{~cm}^{-1}$ and the both the frequency values for all the composition are furnished in Table 5 . 

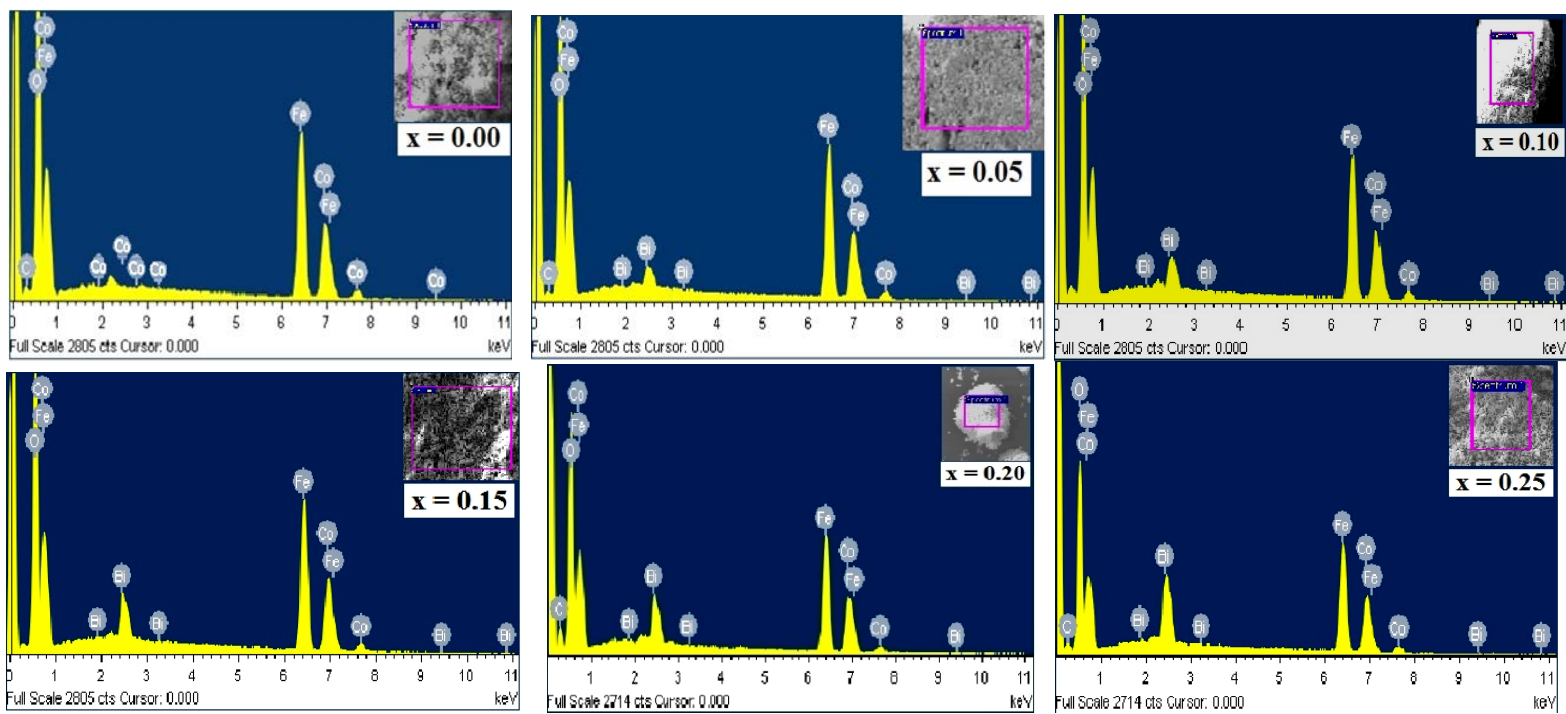

Figure 8. The EDS pattern of $\mathrm{CoBi}_{\mathrm{x}} \mathrm{Fe}_{2-\mathrm{x}} \mathrm{O}_{4}$ nano ferrite particles sintered at $600^{\circ} \mathrm{C}$ with the composition $(\mathrm{x}=0.00$ to 0.25$)$.

Table 4. The relative elemental (\%) and atomic (\%) of composition of $\mathrm{CoBi}_{x} \mathrm{Fe}_{2-\mathrm{x}} \mathrm{O}_{4}$ nano ferrite particles.

\begin{tabular}{cccccccccc}
\hline Element & \multicolumn{2}{c}{$\mathrm{O}$} & \multicolumn{2}{c}{$\mathrm{Co}$} & \multicolumn{3}{c}{$\mathrm{Bi}$} & \multicolumn{3}{c}{$\mathrm{Fe}$} \\
\hline Ferrite composition & Element \% & Atomic \% & Element \% & Atomic \% & Element \% & Atomic \% & Element \% & Atomic \% \\
\hline $\mathrm{CoFe}_{2} \mathrm{O}_{4}$ & 26.34 & 54.76 & 26.27 & 16.23 & -- & -- & 47.39 & 29.01 \\
$\mathrm{CoBi}_{0.05} \mathrm{Fe}_{1.95} \mathrm{O}_{4}$ & 25.57 & 55.85 & 25.26 & 15.33 & 4.25 & 0.71 & 44.92 & 28.11 \\
$\mathrm{CoBi}_{0.10} \mathrm{Fe}_{1.90} \mathrm{O}_{4}$ & 27.01 & 57.31 & 24.90 & 15.23 & 6.14 & 1.14 & 41.95 & 26.32 \\
$\mathrm{CoBi}_{0.15} \mathrm{Fe}_{1.85} \mathrm{O}_{4}$ & 24.85 & 58.12 & 24.32 & 15.12 & 8.94 & 1.42 & 41.89 & 25.34 \\
$\mathrm{CoBi}_{0.20} \mathrm{Fe}_{1.80} \mathrm{O}_{4}$ & 26.63 & 59.14 & 23.13 & 14.22 & 10.49 & 1.92 & 39.75 & 24.72 \\
$\mathrm{CoBi}_{0.25} \mathrm{Fe}_{1.75} \mathrm{O}_{4}$ & 23.65 & 58.91 & 22.87 & 13.98 & 15.46 & 2.94 & 38.02 & 24.17 \\
\hline
\end{tabular}

Table 5. The relative frequency bands of lower and higher of the $\mathrm{CoBi}_{\mathrm{x}} \mathrm{Fe}_{2-\mathrm{x}} \mathrm{O}_{4}$ nano ferrite particles.

\begin{tabular}{ccc}
\hline Ferrite composition & Lower frequency bands $v_{1}\left(\mathrm{~cm}^{-1}\right)$ & Higher frequency bands $v_{2}\left(\mathrm{~cm}^{-1}\right)$ \\
\hline $\mathrm{CoFe}_{2} \mathrm{O}_{4}$ & 592.55 & 393.50 \\
$\mathrm{CoBi}_{0.05} \mathrm{Fe}_{1.95} \mathrm{O}_{4}$ & 591.33 & 369.10 \\
$\mathrm{CoBi}_{0.10} \mathrm{Fe}_{1.90} \mathrm{O}_{4}$ & 593.65 & 384.09 \\
$\mathrm{CoBi}_{0.15} \mathrm{Fe}_{1.85} \mathrm{O}_{4}$ & 596.15 & 385.68 \\
$\mathrm{CoBi}_{0.20} \mathrm{Fe}_{1.80} \mathrm{O}_{4}$ & 591.63 & 368.50 \\
$\mathrm{CoBi}_{0.25} \mathrm{Fe}_{1.75} \mathrm{O}_{4}$ & 592.55 & 385.60 \\
\hline
\end{tabular}

It is observed that the differences in the band positions is expected because of the difference in bond length of $\mathrm{Fe}^{3+}-\mathrm{O}^{2-}$ ions at the octahedral and tetrahedral sites [28]-[30]. Because of tetrahedral dimensions are less with compared to octahedral site dimensions, the absorption bands have inverse relationship with the bond length. It is also observed that, the bands $v_{1}$ and $v_{2}$ were slightly shifted towards higher frequency side with the increase of bismuth content. Due to decrease in site radius, that increase the fundamental frequency and hence the central frequency should shift towards the higher frequency side [31] [32]. 

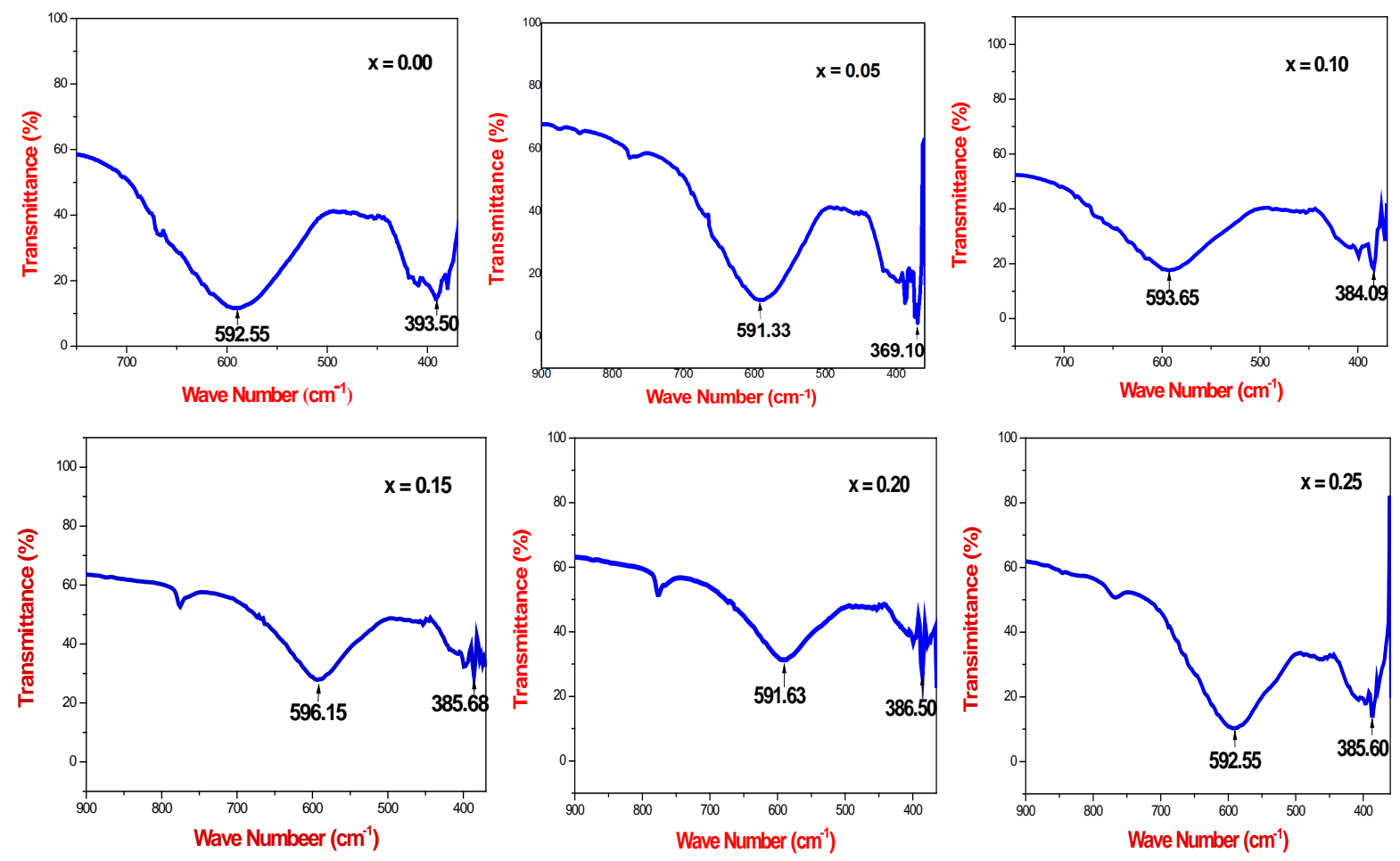

Figure 9. FTIR spectra of all Co-Bi ferrite (CBF) nano particles which are sintered at $600^{\circ} \mathrm{C}$ of the composition Co$\mathrm{Bi}_{\mathrm{x}} \mathrm{Fe}_{2-\mathrm{x}} \mathrm{O}_{4}(\mathrm{x}=0.00$ to 0.25$)$.

\section{Conclusions}

On the basis of above discussion, the following conclusions are drawn

$>$ A series of Bismuth doped Cobalt ferrite with the compositional formula $\mathrm{CoBi}_{\mathrm{x}} \mathrm{Fe}_{2-\mathrm{x}} \mathrm{O}_{4}$ (where $\mathrm{x}=0.00$ to 0.25 ) were prepared by sol-gel method successfully and sintered at $600^{\circ} \mathrm{C}$ for 5 hrs.

$>$ It is observed that the sol-gel combustion method is a convenient way for obtaining a homogeneous nano sized mixed nanoferrites.

$>$ The X-ray diffraction patterns confirm the formation of cubic spinal structure in single phase without any impurity peaks.

$>$ Due to very small amount of $\mathrm{Bi}^{3+}$ ion doping, the molecular weight increases and the unit cell dimensions were shrinkage. Therefore the lattice parameters also decrease with the increase of doping concentration.

$>$ In this system the crystallite size was found to be in the range of $17 \mathrm{~nm}$ to $26 \mathrm{~nm}$.

$>$ The relation between hopping length for tetrahedral site (A-site) and octahedral site (B-site) was investigated as a function of " $\mathrm{X}$ " and it was found to be decrease with $\mathrm{Bi}^{3+}$ ion content. This is due to the difference in ionic radii of $\mathrm{Fe}^{3+}$ and $\mathrm{Bi}^{3+}$ ions.

$>$ The SEM and TEM images show the morphology of the prepared samples at different magnifications. And it is clear that, the SEM images have an almost homogeneous distribution and some of them are agglomerated.

$>$ The particle size is evidenced by TEM images that the aggregation of particles lies in nano scale and conform all the samples were crystalline structure.

$>$ The EDS data gives the elemental \% and atomic \% of Bi doped Cobalt Ferrite system. And which shows the presence of $\mathrm{Co}, \mathrm{Fe}, \mathrm{O}$ and $\mathrm{Bi}($ except $\mathrm{x}=0$ ) participating cations.

$>$ The FT-IR spectra of the compositions under investigation reveal the formation of a single phase cubic spinal structure. This shows two significant absorption bands which confirm the characteristics of ferrite sample.

\section{Acknowledgements}

The authors are thankful to Dr. K.E. Balachandrudu, Principal, MRIET, Secunderabad for providing the necessary facilities to bring out this research work. Dr. K.V.K. is grateful to Prof. N. V. Ramana, Principal, JNTUH 
College of Engineering Jagtial, Nachupally (Kondagattu), Karimnagar-Dist for his encouragement.

\section{References}

[1] Pallai, V. and Shah, D.O. (1996) Synthesis of High-Coercivity Cobalt Ferrite Particles Using Water-in-Oil Microemulsions. Journal of Magnetism and Magnetic Materials, 163, 243-248. http://dx.doi.org/10.1016/S0304-8853(96)00280-6

[2] Skomski, R. (2003) Nanomagnetics. Journal of Physics: Condensed Matter, 15, R1. http://dx.doi.org/10.1088/0953-8984/15/20/202

[3] Kumar, S., Shinde, T.J. and Vasambekar, P.N. (2013) Microwave Synthesis and Characterization of Nano Crystalline Mn-Zn Ferrites. Advanced Materials Letters, 4, 373-377. http://dx.doi.org/10.5185/amlett.2012.10429

[4] Dixit, G., Singh, J.P., Srivastava, R.C., Agrawal, H.M. and Chaudhary, R.J. (2012) Structural, Magnetic and Optical Studies of Nickel Ferrite Thin Films. Advanced Materials Letters, 3, 21-28. http://dx.doi.org/10.5185/amlett.2011.6280

[5] Giannakopoulou, T., Kompotiatis, L., Kontogeorgakos, A. and Kordas, G. (2002) Microwave Behavior of Ferrites Prepared via Sol-Gel Method. Journal of Magnetism and Magnetic Materials, 246, 360-365. http://dx.doi.org/10.1016/S0304-8853(02)00106-3

[6] Pardavi-Horvath, M. (2000) Microwave Applications of Soft Ferrites. Journal of Magnetism and Magnetic Materials, 215-216, 171-183. http://dx.doi.org/10.1016/S0304-8853(00)00106-2

[7] Gupta, N., Dimri, M.C. Kashyap, S.C. and Dube, D.C. (2005) Processing and Properties of Cobalt-Substituted Lithium Ferrite in the GHz Frequency Range. Ceramics International, 31, 171-176. http://dx.doi.org/10.1016/j.ceramint.2004.04.004

[8] Bate, G. (1975) In: Craik, D.J., Ed., L: Magnetic Oxides, Part 2, Wiley Interscience, New York, 703.

[9] Sharrock, M.P. (1989) Particulate Magnetic Recording Media: A Review. IEEE Transactions on Magnetics, 25, 43744389. http://dx.doi.org/10.1109/20.45317

[10] Handley, R.C.O. (2000) Modern Magnetic Materials: Principles and Applications. John Wiley \& Sons, New York.

[11] Chen, D., Zhang, Y. and Tu, C. (2012) Preparation of High Saturation Magnetic $\mathrm{MgFe}_{2} \mathrm{O}_{4}$ Nanoparticles by Microwave-Assisted Ball Milling. Materials Letters, 82, 10-12. http://dx.doi.org/10.1016/j.matlet.2012.05.034

[12] Amighian, J., Mozaffari, M. and Nasr, B. (2006) Preparation of Nano-Sized Manganese Ferrite $\left(\mathrm{Mn}^{-} \mathrm{Fe}_{2} \mathrm{O}_{4}\right)$ via Coprecipitation Method. Journal of Solid State Physics, 3, 3188-3192.

[13] Meenakshisundaram, A., Gunasekaran, N. and Srinivasan, V. (1982) Distribution of Metal Ions in Transition Metal Manganites $\mathrm{AMn}_{2} \mathrm{O}_{4}$ (A: Co, Ni, Cu, or Zn). Physica Status Solidi(a), 69, K15-K19. http://dx.doi.org/10.1002/pssa.2210690149

[14] Pallai, V. and Shah, D.O. (1996) Synthesis of High-Coercivity Cobalt Ferrite Particles Using Water-in-Oil Microemulsions. Journal of Magnetism and Magnetic Materials, 163, 243-248. http://dx.doi.org/10.1016/S0304-8853(96)00280-6

[15] Skomski, R. (2003) Nanomagnetics. Journal of Physics: Condensed Matter, 15, R841-R896. http://dx.doi.org/10.1088/0953-8984/15/20/202

[16] Yang, H., Zhang, X.C., Tang, A.D. and Qiu, G.Z. (2004) Cobalt Ferrite Nanoparticles Prepared by Coprecipitation/ Mechanochemical Treatment. Chemistry Letters, 33, 826-827. http://dx.doi.org/10.1246/cl.2004.826

[17] Brinker, C.J. and Scherer, G.W. (1990) Sol-Gel Science: The Physics and Chemistry of Sol-Gel Processing. Academic Press, San Diego.

[18] Ai, L.H. and Jiang, J. (2010) Influence of Annealing Temperature on the Formation, Microstructure and Magnetic Properties of Spinel Nanocrystalline Cobalt Ferrites. Current Applied Physics, 10, 284-288. http://dx.doi.org/10.1016/j.cap.2009.06.007

[19] Bensebaa, F., Zavaliche, F., L’Ecuyer, P., Cochrane, R.W. and Veres, T. (2004) Microwave Synthesis and Characterization of Co-Ferrite Nanoparticles. Journal of Colloid and Interface Science, 277, 104-110. http://dx.doi.org/10.1016/j.jcis.2004.04.016

[20] El Haiti, M.A. (1994) DC Conductivity for $\mathrm{Zn}_{x} \mathrm{Mg}_{0.8-x} \mathrm{Ni}_{0.2} \mathrm{Fe}_{2} \mathrm{O}_{4}$ Ferrites. Journal of Magnetism and Magnetic Materials, 136, 138-142. http://dx.doi.org/10.1016/0304-8853(94)90457-X

[21] Khan, H.M., Misbah-ul-Islam, Ali, I. and Rana, M. (2011) Electrical Transport Properties of $\mathrm{Bi}_{2} \mathrm{O}_{3}-\mathrm{Doped} \mathrm{CoFe}_{2} \mathrm{O}_{4}$ and $\mathrm{CoHo}_{0.02} \mathrm{Fe}_{1.98} \mathrm{O}_{4}$ Ferrites. Materials Sciences and Application, 2, 1083-1089.

[22] Kawade, V.B., Bichile, G.K. and Jadhav, K.M. (2000) X-Ray and Infrared Studies of Chromium Substituted Magnesium Ferrite. Material Letters, 42, 33-37. http://dx.doi.org/10.1016/S0167-577X(99)00155-X

[23] Arulmurugan, R., Jeyadevan, B., Vaidyanathan, G. and Sendhilnathan, S. (2005) Effect of Zinc Substitution on Co-Zn and Mn-Zn Ferrite Nanoparticles Prepared by Coprecipitation. Journal of Magnetism and Magnetic Materials, 288, 
470-477. http://dx.doi.org/10.1016/j.jmmm.2004.09.138

[24] Goldman, A. (1990) Modern Ferrite Technology. Van No Strand Reinhold, New York.

[25] Iqbal, M.J. and Siddiquah, M.R. (2008) Electrical and Magnetic Properties of Chromium Substituted Cobalt Ferrite Nano Materials. Journal of Alloys and Compounds, 453, 513-518. http://dx.doi.org/10.1016/j.jallcom.2007.06.105

[26] Maaz, K., Mumtaz, A., Hasanain, S.K. and Ceylan, A. (2007) Synthesis and Magnetic Properties of Cobalt Ferrite $\left(\mathrm{CoFe}_{2} \mathrm{O}_{4}\right)$ Nanoparticles Prepared by Wet Chemical Route. Journal of Magnetism and Magnetic Materials, 308, 289295. http://dx.doi.org/10.1016/j.jmmm.2006.06.003

[27] Zhou, B., Zhang, Y.W., Liao, C.S., Yan, C.H., Chen, L.Y. and Wang, S.Y. (2004) Rare-Earth-Mediated Magnetism and Magneto-Optical Kerr Effects in Nano-Crystalline CoFeMn ${ }_{0.9} \mathrm{RE}_{0.1} \mathrm{O}_{4}$ Thin Films. Journal of Magnetism and Magnetic Materials, 280, 327-333. http://dx.doi.org/10.1016/j.jmmm.2004.03.031

[28] Zaki, H.M. and Dawoud, H.A. (2010) Far-Infrared Spectra for Copper-Zinc Mixed Ferrites. Physica B, 405, 4476-4479. http://dx.doi.org/10.1016/j.physb.2010.08.018

[29] Kambale, R.C., Song, K.M., Koo, Y.S. and Hur, N. (2011) Low Temperature Synthesis of Nano Crystalline Dy3p Doped Cobalt Ferrite: Structural and Magnetic Properties. Journal of Applied Physics, 110, Article ID: 053910. http://dx.doi.org/10.1063/1.3632987

[30] Srivastava, M., Chaubey, S. and Ojha, A.K. (2009) Investigation on Size Dependent Structural and Magnetic Behavior of Nickel Ferrite Nanoparticles Prepared by Sol-Gel and Hydrothermal Methods. Materials Chemistry and Physics, 118, 174-180. http://dx.doi.org/10.1016/j.matchemphys.2009.07.023

[31] Maensiri, S., Masingboon, C., Boonchom, B. and Seraphin, S. (2007) A Simple Route to Synthesize Nickel Ferrite $\left(\mathrm{NiFe}_{2} \mathrm{O}_{4}\right)$ Nanoparticles Using Egg White. Scripta Materialia, 56, 797-800. http://dx.doi.org/10.1016/j.scriptamat.2006.09.033

[32] Srivastava, M., Ojha, A.K., Chaubey, S., Sharma, P.K. and Pandey, A.C. (2010) Influence of pH on Structural Morphology and Magnetic Properties of Ordered Phase Cobalt Doped Lithium Ferrites Nanoparticles Synthesized by SolGel Method. Materials Science and Engineering B, 175, 14-21. http://dx.doi.org/10.1016/j.mseb.2010.06.005 